\title{
TURISMO PÓS-MODERNO: DILEMAS E PERSPECTIVAS PARA UMA GESTÃO SUSTENTÁVEL
}

\author{
Hermógenes Henrique Oliveira Nascimento \\ Bacharel em Turismo - UFRN e Estudante do Curso de Especialização em Gestão \\ Ambiental - IFRN \\ henrique.sampa@gmail.com
}

Valdenildo Pedro da Silva

Prof. Dr. Em Geografia - Instituto Federal do Rio Grande do Norte

E: valdenildo@cefetrn.br

\begin{abstract}
RESUMO
No contexto de uma nova ordem do mercado global, o presente estudo visa analisar uma das fases do turismo, em especial, a do turismo pós-moderno compreendendo os seus dilemas e perspectivas para uma gestão sustentável. Este artigo busca fornecer subsídios aos planejadores e gestores de turismo das cidades que desejam se tornar um destino sustentável. O estudo, inicialmente, retrata algumas referências que embasaram com seus conceitos à temática em questão, enfocando quais elementos que contribuíram para o crescimento do turismo e, posteriormente, apresenta as características do turismo de massa e os seus impactos ambientais; do turismo na pós-modernidade e suas considerações relacionadas a uma ética ambiental e, por fim, a idéia de gestão turística sustentável. É importante destacar que a metodologia adotada na construção do trabalho foi a de análise de conteúdo proposta por Bardin que a partir de técnicas com tópicos centrais da pesquisa e revisões bibliográficas visou explicar de forma qualitativa o processo de interpretação deste artigo. Em suma, constatou-se que esse novo arranjo do turismo planejado pode contribuir de forma eficiente para uma gestão sustentável da atividade.
\end{abstract}

PALAVRAS-CHAVE: turismo de massa, turismo pós-moderno, gestão sustentável.

\section{POST-MODERN TOURISM: DILEMMAS AND PROSPECTS FOR SUSTAINABLE MANAGEMENT}

\begin{abstract}
In the context of a new order of global market, this study aims to examine one of the tourism, especially the post-modern tourism, understanding their dilemmas and prospects for sustainable management. This article aims to provide grants for tourism planners and managers of cities that want to become a sustainable destination. The article initially portrays some references that based their concepts with the subject in question, focusing on factors which contributed to the growth of tourism and, later, has the characteristics of mass tourism and its environmental impacts, tourism in post-modernity and its considerations related to an environmental ethics, and finally the idea of sustainable tourism management. It is important to emphasize that the methodology adopted in the construction work was the analysis of content proposed by Bardin that from technical topics central to the work and bibliographic review aimed to explain how the process qualitative interpretation of this article. In short, it was found that this new arrangement in planned tourism can contribute efficiently to the sustainable management of the activity.
\end{abstract}

KEY-WORDS: mass tourism, post-modern tourism, sustainable management. 


\section{TURISMO PÓS-MODERNO: DILEMAS E PERSPECTIVAS PARA UMA GESTÃO SUSTENTÁVEL}

\section{INTRODUÇÃO}

Da sociedade mercantil do século XV à moderna economia global do século XXI, as forças produtivas vêm propiciando um crescimento das potencialidades do homem que pareceria impossível de se imaginar há quinhentos, duzentos, cinqüenta, ou mesmo, dez anos atrás. Paradoxalmente, quanto maior o potencial humano decorrente da capacidade infinita de gerar conhecimento, mais incerto é o futuro. Parece que a sociedade contemporânea está avançando em sinais vermelhos que desafiam sua capacidade em se ajustar a mudanças cada vez mais rápidas.

Dessa forma, sob esse cenário evolutivo da nossa sociedade, que o turismo moderno se transformou em uma atividade de grande relevância no mundo em termos quantitativos, a partir da produção de um grande número de deslocamentos, em virtude do avanço tecnológico dos meios de transporte; da geração de empregos e, em alguns casos, da elevação no nível de renda de comunidades, cidades e até países (ANDRADE, 1992). Embora, alguns autores ainda mencionem que no inicio do desenvolvimento do turismo de massa após a Segunda Guerra Mundial, este tenha trazido alguns impactos positivos, em razão dos benefícios proporcionados pelo lazer. Todavia, no decorrer do texto, será constatado que essa massificação do turismo, de fato, só acarretou diversos impactos negativos.

Segundo Ruschmann (1997), o turismo pode ser uma opção ao desenvolvimento das comunidades e das pessoas. No entanto, é necessário um planejamento rigoroso, contando com a participação da comunidade envolvida para que possa ser bem sucedido. Fato é, pelas estatísticas já veiculadas pela Organização Mundial do Turismo (OMT, 2006), que aproximadamente de 6 a 8\% do total de empregos gerados no mundo depende do turismo e que o turismo é o segmento que movimenta de forma direta $10 \%$ do PIB - Produto Interno Bruto mundial, ou seja, é uma atividade que mais cresce atualmente no mundo (LAGE e MILONE, 2000), só perdendo para a indústria petrolífera, além de envolver relações sociais e econômicas, também implica questões de especulação e conflitos ambientais. Em conforme a estes fatores, faz-se necessário investigar as suas conseqüências e impactos nos setores da sociedade.

Em contrapartida, de forma emergente, a atividade turística pós-moderna ganha impulso e se modela aos princípios da sustentabilidade, pois proporciona experiências de grande valor emocional, uma vez que oferece a possibilidade de interação com o meio e a cultura local, promovendo uma ruptura do cotidiano (WAINBERG, 1998; URRY, 1999). Ao refletir sobre o turismo não só como uma forma de lazer e autoconhecimento, mas também como um fenômeno que relaciona pessoas de diferentes identidades culturais, este estudo elucida a questão das relações socioambientais, especificamente de que forma o turismo pós-moderno ou pós-turismo pode corroborar com a sua concepção para uma gestão turística sustentável.

Cabe mencionar que o modelo de gestão para um destino ser sustentável é aquele que adota um conjunto de medidas sistêmicas, realizáveis e de seu planejamento duradouro, que se estende a todas as fases do ciclo de vida de um destino turístico e concatena seu desenvolvimento nos eixos do contexto econômico, sociocultural e ambiental. Nesse sentido Ignarra (2001), avança neste enfoque ao falar que qualquer destinação de turismo possui seu ciclo de vida, e assim ele destaca que as etapas são: Exploração, 
Desenvolvimento, Consolidação, Estagnação, Rejuvenescimento ou Declínio. Desta forma, acredita-se que para se manter um destino consolidado ou, se for o caso, partir para uma fase de rejuvenescimento é preciso constante aprimoramento e reposicionamento de mercado afim de conservar o que já existe e atrair novas oportunidades.

Em vista disso, é preciso trazer à tona, os pilares que construíram o conceito de turismo sustentável e que irão direcionar todo este artigo na forma de estruturação do turismo pósmoderno, pois de acordo com a OMT, com base no Relatório de Brundtland, em 1987, define turismo sustentável como aquele que:

“[...] atende às necessidades dos turistas atuais e das regiões receptoras $\mathrm{e}$ ao mesmo tempo protege e fomenta as oportunidades para o turismo futuro. [...] respeitando ao mesmo tempo a integridade cultural, os processos ecológicos essenciais, a diversidade biológica e os sistemas que sustentam a vida”. (OMT apud DIAS, R., 2003, p.68).

Vale ressaltar que com essa mesma ideologia do Relatório, pode-se traçar o escopo que norteia os fundamentos do pós-turismo. Percebe-se dando continuidade ao desenvolvimento do artigo, que a gestão sustentável da atividade de acordo com Beni (2001) exige um planejamento do turismo, além de ter um sistema integrado com as outras atividades locais e também deve ter na sua estrutura um plano de longo prazo e projetos estratégicos.

Como forma de justificar o nascimento deste trabalho, pode-se mencionar Castrogiovanni (2003, p.45), pois ele defende que:

O turismo não nasceu de uma teoria, mas de práticas espontâneas que foram se configurando por si mesmas, o que parece justificar em parte, a leitura fluente, que insiste em tratar o turismo empiricamente e como devorador de paisagens e lugares. É hora de propor uma intervenção inovadora do fazer-saber turístico [...] através da desconstrução do saber-fazer (MOESCH, 2000). A desconstrução é o instrumento mais adequado para romper paradigmas tão sedimentados e criar leituras que forcem a necessidade da questionabilidade contínua relativa aos saberes e informações, transformando-os em verdades provisórias e caminhos com opções diferenciadas.

Em face do exposto, colocando em foco a problemática, a pesquisa em tela volta-se, inicialmente, para avaliar o histórico do turismo de massa com seus impactos; e, posteriormente, desenvolve a discussão dos desafios e das perspectivas do turismo pósmoderno como forma de contribuir para uma gestão sustentável da atividade. O estudo parte do pressuposto de que analisando diversos autores que defendem uma nova concepção de desenvolvimento turístico, tais implicações serão mais bem fundamentadas para elucidar alguns questionamentos que são: Qual o propósito deste pós-turismo?; De que forma esta atividade pode ser sustentável no seu gerenciamento ao longo do tempo?; Quais os gargalos encontrados que entravam o desenvolvimento do turismo pósmoderno?; E quais as perspectivas deste turismo para fomentar uma ética ambiental na sociedade?.

\section{TURISMO DE MASSA E IMPACTOS AMBIENTAIS}

Pode-se dizer que o turismo é um setor em franco crescimento em termos de economia global. Desde os anos de 1950, quando as viagens internacionais tornaram-se acessíveis ao 
público em geral, o número de turistas vem crescendo a uma taxa média de $6,8 \%$ ao ano (OMT, 2005).

De acordo com estimativas da OMT (2006), o número de desembarques de turistas, em 2005, teria alcançado 808 milhões ao redor do mundo. As tendências para o futuro da atividade do turismo apontam que, até 2020, o desembarque internacional de turistas chegue próximo de 1,6 bilhão, o equivalente a $20 \%$ da população mundial. Esse órgão, espera que até 2020, o setor global do turismo cresça a uma taxa efetiva de 4,1\% (WTO, 2005).

Segundo dados estatísticos do Ministério do Turismo (BRASIL, 2005), após três anos seguidos de crescimento abaixo da média (2001-2003), a taxa de crescimento, no ano de 2004 , foi de $11 \%$, o maior percentual e o único com dois dígitos desde 1980 , quando se iniciou a coleta de dados detalhados do setor. Também em 2004, as receitas provenientes do turismo global bateram o maior recorde de todos os tempos, atingindo, aproximadamente, US\$ 622,7 bilhões, resultantes de 763,2 milhões de desembarques de turistas internacionais.

Observa-se que esse volume de números se deve, em grande parte, pela expressão do turismo de massa ou tradicional que se refere ao turismo iniciado no século XIX após a Revolução Industrial e intensificado no século seguinte após a Segunda Guerra Mundial. Esta atividade tinha característica principal de ser um fenômeno do mundo industrializado que ocorre em função da existência de tempo livre, da melhoria da qualidade de vida, do desenvolvimento dos meios de comunicação, de transporte e das novas tecnologias existentes (BARRETTO, 1995; DANTAS, 1999).

Nesse direcionamento, fruto da modernidade, o turismo de massa também se modifica e se populariza como atividade humana do lazer moderno; é decorrente de transformações sociais e econômicas, as quais somente surgem e se concretizam no século passado, em virtude das conquistas trabalhistas; entre outros fatores que eclodem nas grandes metrópoles turísticas, que em momentos de lazer cada vez mais pessoas descobrem oportunidades para viagens de turismo.

Já Ruschmann (1997) caracteriza o turismo de massa pelo grande volume de pessoas que viajam em grupos ou individualmente para os mesmos lugares, geralmente nas mesmas épocas do ano. Esse tipo de turismo acaba sendo considerado o grande responsável pelas agressões dos espaços naturais, pois o excesso de turistas leva ao super-dimensionamento dos equipamentos relacionados à superestrutura dos meios turísticos, que ocupam grandes espaços, agridem paisagens e destroem ecossistemas. E observa-se que, a cultura turística destes visitantes geralmente mostra pouca ou nenhuma preocupação com a preservação da natureza ou da cultura local.

Sob esse cenário, a OMT (2006) constata que o turismo de massa ainda está na sua fase inicial pois, diferentemente do turismo elitista, conserva ainda uma importante demanda latente ou potencial, dependendo, portanto da conjuntura econômica e particularmente do aumento do poder aquisitivo da população de classe média gerando um público-alvo com avidez para realizar viagens. Entretanto, acredita-se que este posicionamento da OMT sobre a classe média precisa ser enfrentado, ou seja, precisa-se diagnosticar e agir com planejamento estratégico a melhor forma de conceber o turismo de massa para que os destinos não tenham a sua capacidade de carga sobrecarregada com demandas ainda não preparadas para desfrutar com responsabilidade socioambiental das paisagens turísticas. Vale destacar que a educação para o turismo é uma das alternativas para um melhor aproveitamento das viagens. 
O turismo convencional traz impactos mais negativos à área de destino do turista que o turismo alternativo. O turismo convencional ou de massa, de acordo com Fennell (2002), caracteriza-se por dominar o turismo de uma região, além de contribuir muito pouco para o desenvolvimento local, visto que os recursos financeiros não ficam na região. Logo, o hotel e demais equipamentos são, em geral, produzidos com produtos externos, há pouca demanda para alimentos regionais e o marketing incentiva um número elevado de pessoas, muitas vezes marcadas pela sazonalidade da demanda, o que influencia nos níveis de emprego ofertados na localidade, alterando o ritmo de vida da população local, e direcionando as ações para satisfazer às expectativas e demandas dos clientes.

Por esse ponto, constata-se que o turismo mal planejado e com uma gestão deficiente pode ter efeitos negativos simbolizando perigos para a região e trazendo impactos ao meio ambiente de tipos e modos específicos, como prejuízos para o solo e para a vegetação, poluição para os cursos de água, perda da vida da flora, fauna e habitat selvagem e aumento da quantidade de lixo em locais visitados, além do vandalismo nos ecossistemas naturais e outros impactos ambientais indiretos.

Ao escrever sobre o impacto ambiental do turismo Cooper et al (2001, p. 186) afirma que:

Não existem modelos que tenham aceitação geral para a avaliação de impacto ambiental (AIA). Em muitas destinações turísticas ambientalmente sensíveis, há poucos atos legislativos e ainda menos órgãos com poderes para salvaguardar o meio ambiente com relação ao desenvolvimento do turismo [...].

Deste modo, entende-se para que o segmento do turismo seja aproveitado com maior responsabilidade, rentabilidade e menores impactos nocivos ao meio ambiente é preciso identificar precocemente os impactos ambientais associados ao desenvolvimento das atividades do turismo, antes que a natureza possa sentir de forma perniciosa e definitiva a presença da atividade humana.

De acordo com tudo aqui elencado, as discussões sobre o turismo de massa são importantes parâmetros para o turismólogo pensar, analisar e propor medidas para toda uma cadeia produtiva que cerca a atividade, pois isso serve como suporte para implementar um turismo mais racional e são tendências que vêm se confirmando em novas formas de gestão que vão ser apresentadas no decorrer do trabalho.

\section{TURISMO PÓS-MODERNO E ÉTICA AMBIENTAL}

Quando se analisa o turismo pós-moderno partindo de uma escala global, considerando as diferenças existentes entre as regiões do planeta, permiti-se questionar qual a gestão que se têm praticado nesses destinos, visando identificar que características as tornam mais evidentes, uma vez que se apresentam de forma exótica no mercado turístico, e, logo vai exigir dos pesquisadores uma apreciação criteriosa deste novo arranjo do turismo. E sendo assim, podemos examinar até que ponto o cenário atual do turismo em destinos mais novos é semelhante ao de destinos consolidados. E como se apresentam estes novos produtos turísticos no decorrer deste século XXI.

Desta maneira, de acordo com Harvey (1992), analisar o momento contemporâneo sob as questões implícitas no que se pode chamar de pós-modernidade, permite avançar na reflexão do turismo não apenas no enfoque de uma atividade do capitalismo financeiro, mas na sua inter-relação com os fenômenos sociais, culturais e ambientais dos quais ele é 
parte integrante e que, se por um lado, ele os afeta, como tantos autores tem analisado, ele é também submetido e afetado.

Ao contrário do turismo massificado, predominante nas décadas de 50 a 70, a nova tendência da atividade turística é o turismo alternativo, de acordo com Krippendorf (2000), personalizando o produto turístico, atendendo às expectativas do turista, que cada vez mais valoriza experiências pessoais significantes. Dessa forma, aborda-se que o pósturismo compartilha com essa tendência de expressão por experiências gratificantes que possibilitam o sentir da cultura que está se visitando e o sentir das peculiaridades características do local. Estas são algumas das razões pelas quais o turismo cultural, ecológico e naturalista têm crescido na preferência das pessoas, logo novas identidades pós-modernas irão se desenvolver, especialmente, em novas demandas criadas e materializadas em diferentes estilos de vida e viagem.

Por essa nova tendência apresentada, a OMT (2006) em seu relatório Barômetro de Viagens e Turismo projeta que o crescimento anual no fluxo turístico da Europa a partir de 2020 será de 4,6\% contra os 3,3\% atuais. No entanto, essas estatísticas mostram que os países do leste terão índices ainda maiores: 8,5\% na Federação Russa; 8,4\% na Croácia; 6,2\% na Eslovênia; 5,5\% na Turquia e 5,2\% na Bulgária. Tais regiões podem ser rotuladas como reservatórios de curiosidade, o que explica seu grande poder de atração de demanda turística pós-moderna. Em outras palavras, podemos inferir que destinos com culturas exóticas, paisagens singulares e história pouco conhecida pela mídia serão os nichos do mercado turístico do futuro.

De acordo com esse panorama apresentado, a concepção de Van der Berghe (1994, p.129) vai de encontro com o nosso pensamento, pois defende que: "os turistas independentes interagem muito mais com os nativos e de maneiras mais variadas comparados aos turistas guiados”. De tal maneira, deve-se ater que um novo perfil de turista mais consciente e mais ético é necessário para uma atividade turística mais responsável, uma vez que é fundamental a interação respeitando as culturas locais.

Percebe-se que o pós-turista é um consumidor que busca qualidade diversificada nos serviços do destino visitado, valorizando a cultura em toda a sua complexidade e particularidade, movimentando-se em busca de ícones que representam a identidade local e a memória coletiva representado pelos bens culturais materiais e imateriais que compõem o patrimônio. Este turista também tem a consciência que as paisagens naturais devem ser preservadas, pois faz parte de um ambiente que vai oferecer as populações envolvidas uma sobrevivência mais qualitativa, com boas expectativas para o crescimento de gerações futuras que façam parte desta história. Logo, a formação ambiental e cultural desta nova demanda remete a um conjunto de experiências, fatos históricos e elementos comuns vivenciando por esse perfil diferente de consumidores mais responsáveis pelo desenvolvimento de um turismo sustentável.

Assim sendo, este perfil de turista é uma pessoa cuja confiança não se ganha facilmente, e que já não aceita pacotes pré-determinados por agentes de viagens, indicando que tipo de atrativo ele deve consumir, uma vez que o próprio viajante quer movimentar-se entre os contrastes e descobrir novos atrativos para ser visitado.

E como forma de enfatizar esse contexto Talaya (2004) afirma que:

há um perfil tradicional de turistas, que com o passar do tempo e das diversas adaptações ocorridas, levando-se em consideração principalmente às inovações científicas e tecnológicas, darão origem a 
novos perfis de turistas, como também a uma maior segmentação de mercados e de destinos turísticos.

O referido autor assegura que os aspectos que motivavam a viagem mudaram. Um exemplo é o destino de sol e praia, considerado dentro das opções de motivação tradicional, que agora passa a ser substituído por diversos outros tipos de destinos, com características distintas desta, como por exemplo: o turismo cultural, o ecoturismo, turismo rural, entre outros. Essas mudanças de comportamento que também tem influência devido às questões ambientais estão alterando a estrutura do comportamento de mercado, que tenta se adaptar, segmentando-se em função da diversidade da nova demanda.

Nesse tocante de busca por um diferencial, pode-se mencionar uma particularidade para a atração de visitantes para novos destinos que é o exotismo do lugar que passa a ser uma característica cada vez mais valorizada no mercado do turismo. Por isso Ribeiro (1999, p.28) descreve esse turista contemporâneo ou pós-moderno como um indivíduo que tem a necessidade de se diferenciar, através de ideologias ambientalistas, buscando a reestruturação de sua própria identidade.

Do mesmo modo, Sampaio (2000) infere que para atrair esses novos turistas a adoção dos preceitos da sustentabilidade neste modelo de destino turístico determina antes de tudo uma mudança ideológica, a partir da qual, o desenvolvimento local duradouro passa a ser o objetivo a alcançar, o que não significa a prevalência de um dos sistemas sobre os outros, muito menos o abandono de um deles, mas passa a incluir a referida equidade e equilíbrio no desenvolvimento da tríade econômico/sociocultural/ambiental.

Em defesa da viabilidade econômica da implantação de princípios de sustentabilidade, pelo o respeito ao meio ambiente e às questões socioculturais, a OMT (2001) cita a crescente demanda de turistas conscientes em busca de destinos bem conservados (em cada um de seus aspectos), que possam atender a esta exigência, inclusive estando dispostos a pagar mais pelo produto que vá ao encontro de suas necessidades. Atualizando essa citação posta, podemos acrescentar que no Fórum Econômico Mundial do ano corrente foi elaborado um Relatório de Competitividade do Turismo e Viagem e nele tentava-se mensurar a percentagem de turistas que buscavam o turismo sustentável e se chegou, assim, em um percentual que acreditam ser em torno de $6 \%$ do total de cerca de 1 bilhão de turistas que viajam pelo mundo atualmente. Logo, podemos observar que é um número baixo, porém com possibilidades reais de aumento devido ao maior engajamento de todo o trade turístico, de governos, de entidades e de turistas que começam a entender que a sustentabilidade no turismo é o melhor caminho.

E de fato, para se obter êxito nesse envolvimento de todos que fazem o turismo é necessário que se viabilize um planejamento como processo a serviço do bem-estar e da sustentabilidade, segundo Hall (2004), é inquestionável o fato de que o planejamento aponta na direção do futuro, da construção de um cenário desejável e,

[...] ele pode minimizar impactos potencialmente negativos, maximizar retornos econômicos nos destinos e, desta forma, estimular uma resposta mais positiva por parte da comunidade hospedeira em relação ao turismo no longo prazo. (HALL, 2004, p 29)

Em análise, pode-se argumentar que os turistas querem vivenciar atividades autênticas nos lugares, eventos e festas, deixando de ser atores coadjuvantes para se tornar ativos na comunidade local. Isso significa que os grupos de turistas serão cada vez menores, 
propiciando intimidade entre as pessoas, que podem mudar a programação, por meio de um clima de cumplicidade.

E como forma de abalizar este assunto, segundo dados da OMT (2001), do documento Visão do Turismo 2020, constata-se que as projeções para a África, o Leste e Sul da Ásia, o Pacífico e o Oriente Médio serão crescentes em número de visitantes com o perfil de pós-turistas, em contrapartida, logo continentes como Europa e América haverá uma retração do fluxo turístico, o que nos leva a acreditar que as perspectivas para o desenvolvimento do turismo pós-moderno são positivas em regiões privilegiadas do ponto de vista do seu patrimônio natural e cultural, mas pobres, economicamente, o que requer cuidado especial no planejamento destas localidades.

Todavia, tudo exposto até agora neste trabalho não terá validade, se a construção para uma nova ética no turismo não for consolidada e difundida em toda sociedade. E já quando se aborda a questão da ética ambiental no turismo, busca-se a compreensão de uma diferente postura comportamental de todos os setores da atividade turística frente à natureza e já nesta linha do pensamento ecológico Boff (2004, p. 22) cita que: “ético seria também potenciar a solidariedade generacional no sentido de respeitar o futuro daqueles que ainda não nasceram”.

Refletindo sobre essa visão exposta acima, o turismo ambientalmente correto oferece um modelo mais próximo do adequado para que toda a gestão do trade turístico procure trabalhar respeitando a legislação ambiental, dentro dos parâmetros adequados nas limitações impostas pelos ambientes naturais dos locais de visitação. Portanto, o turismo sustentável não trata de um segmento turístico, mas de um modelo a ser seguido por todos os setores turísticos contribuindo para o desenvolvimento futuro de uma localidade.

Em síntese, como forma de compreender a importância do turismo pós-moderno, pode-se trazer em tela o conceito de turismo sustentável, dado por Ferreira (2004, p.74) que diz:

Turismo sustentável é aquele que atende às necessidades do mercado, dos turistas atuais e das comunidades anfitriãs, utilizando os recursos naturais e culturais, sem comprometer a possibilidade do usufruto desses mesmos recursos pelas gerações futuras.

Em outras palavras, de certo modo, é possível entender o turismo pós-moderno à luz do turismo sustentável, uma vez que a terminologia do termo daquele ainda não está oficializada pela OMT, porém vem sendo estudada por vários autores ainda com certas divergências de conceitos, no entanto neste artigo, pela revisão das fontes consultadas, se preferiu adotar uma linha de pensamento próxima das premissas do turismo mais ético e com responsabilidade socioambiental que é defendida também por Van der Berghe que é uma das referências deste tema.

\section{GESTÃO TURÍSTICA SUSTENTÁVEL}

Observa-se que, nos últimos anos, cresce as estatísticas favoráveis do turismo no mundo e no Brasil, não é diferente, pois aqui tem apresentado bons resultados em relação aos fluxos turísticos, nacionais e internacionais, mostrando ser uma atividade de grande potencial para o desenvolvimento econômico do país. Não obstante estes resultados e os avanços obtidos com a Política Nacional do Turismo, decorrentes da descentralização do Plano Nacional de Turismo 2003/2007, ainda são apontadas limitações no que se refere à integração entre as diferentes esferas de governo, entre o setor público e o setor privado, 
com repercussão também no planejamento da atividade, na articulação e na avaliação dos resultados. Entendemos que precisa ser mudada a forma coadjuvante da administração do turismo neste cenário, ou melhor, é necessário atuar protagonizando nas diversas funções que agregam a atividade contribuindo para aumentar a participação da sociedade no processo de gestão.

Acredita-se que a proposta de gestão deve funcionar como um sistema nacional de planejamento, onde fique clara a participação e a responsabilidade de cada nível de administração pública e privada, com as suas respectivas parcerias. Para que isto aconteça é fundamental a definição de referenciais de planejamento e gestão para o turismo nestas diversas escalas de atuação, tais como planos e programas, de forma articulada.

Compactuando dessa mesma idéia e reforçando o papel público na atividade, Elliott (1997) argumenta que só os governos têm força suficiente para garantir a estabilidade política, a segurança e a estrutura legal e financeira que o turismo requer. Com esse mesmo foco Ignarra (2002, p.125) considera que "não é possível produzir turismo sem que haja direta e indiretamente uma participação do poder público”, pois a ação governamental tem papel estratégico no seu desenvolvimento.

Fazendo uma breve alusão crítica ao turismo de massa, a gestão desta atividade continua a atender a grupos de visitantes que utilizam o serviço de agências ou operadoras de viagens para a organização de sua viagem. Estas, por sua vez, são realizadas sem nenhuma customização, priorizando a visitação dos principais atrativos num curto espaço de tempo, muitas vezes aquém daquele necessário ao seu desfrute adequado. Como resultado deste tipo de desenvolvimento turístico, os principais destinos dos estados encontram-se superlotados e a experiência turística por eles possibilitada é negativamente impactada pela quantidade excessiva de visitantes e pelo perfil da visitação, com estada em grandes hotéis, sobrecarga na visitação de atrativos facilmente acessíveis e baixa interação com as localidades visitadas em si.

Dessa maneira, a visitação em massa é uma das mais destacadas características do turismo hoje realizado no litoral Nordeste do Brasil. Segundo o Ministério do Turismo (BRASIL, 2005), os destinos de sol e praia atraem turistas de nível sócio-econômico médio, cuja permanência está diretamente atrelada aos pacotes adquiridos junto a operadoras de viagens, dificilmente superando os cinco a sete dias. São visitantes com gastos programados, que visitam apenas os principais atrativos dos destinos mais conhecidos do estado e o fazem junto a grandes grupos de visitantes, o que pode diminuir a experiência turística vivida.

Entretanto, os objetivos deste artigo perpassam em assegurar que o turismo pós-moderno pode e deve contribuir com uma gestão mais sustentável da atividade. E deste modo, para alcançar esse fim pode-se mencionar Beni (1991, p.7), que traz três elementos importantes para a gestão futura do turismo que são: inovação (criatividade, imaginação, questionamentos), desempenho (produtividade) e qualidade (profissionalismo e busca permanente da satisfação do cliente).

Ao abordar esses elementos Beni (1991), traduz as bases conceituais do pós-turismo que é defendida nesta pesquisa, pois se acredita que a gestão para desenvolvimento racional da atividade turística deve ser pautada por esses elementos citados e em princípios e práticas que auxiliem a consecução do cenário de desenvolvimento desejado, otimizando os serviços prestados. Nessa conjuntura, tais informações do turismo pós-moderno visam ao desenvolvimento e posterior manutenção da atividade turística e pretendem minimizar a ocorrência de práticas ambientais, econômicas ou socialmente insustentáveis. 
Neste momento, pela construção de conhecimento obtido ao longo deste trabalho, podemse trazer à baila algumas linhas norteadoras para a gestão estratégica do pós-turismo que podem seguir tais vertentes:

- Preservação da natureza e manutenção da biodiversidade;

- Valorização da diversidade cultural tangível e intangível dos grupos sociais;

- Incentivo à construção de equipamentos e estruturas físicas economicamente viáveis e associadas à paisagem (natural ou urbana) em que se localizam;

- Incentivo à criação de produtos turísticos voltados para diferentes públicos, considerando turistas locais, regionais, nacionais e internacionais;

- Apoio ao desenvolvimento de nichos de mercado alternativos ao turismo de massa;

- Fomento à ampliação espacial dos destinos turísticos do estado, visando à interiorização e desconcentração da atividade no litoral;

- Expansão das oportunidades de emprego e renda para a população do estado;

- Investimento nos recursos humanos como forma de desenvolvimento do turismo;

- Busca pela qualidade na prestação dos serviços turísticos;

- Cooperação entre setores públicos, privados e terceiro setor em nível municipal, regional, estadual e nacional;

- Atuação conforme marcos regulatório e legal do estado, considerando peculiaridades locais e regionais.

Logo, com todas essas diretrizes coordenadas se espera ter um destino turístico sustentável, com uma gestão eficiente fomentando uma cidade saudável. Assim sendo, preconizam-se como resultados: serviços aprimorados e personalizados ofertados pelos receptivos aos seus visitantes; uma atitude coletiva favorável ao turismo; a postura comunitária consciente dos benefícios que a atividade é capaz de proporcionar, sendo a cidade a própria empresa turística; a valorização de uma identidade cultural material e imaterial em todos os aspectos do município/região visitado; logo a auto-estima dos povos locais será marcante e o compromisso com a ética do mercado será priorizado em toda a cadeia produtiva do turismo.

Tem-se a noção de que o primeiro passo já foi dado, apesar de ainda ser um processo lento e com muitos entraves como já foi discutido aqui, porém devemos avançar em todas as esferas de gestão e administração, focando para o desenvolvimento e implementação dos mecanismos de acompanhamento e avaliação de desempenho da atividade turística; seja no âmbito da eficácia das ações específicas, deflagradas para alcançar os objetivos e metas propostas; seja com relação à efetividade dos resultados para o desenvolvimento do turismo, com sustentabilidade.

\section{METODOLOGIA}

Neste item apresentam-se os caminhos percorridos durante a realização da pesquisa, seu delineamento e escopo, métodos e técnicas empregados. Logo, Nascimento (2007, p.23) diz:

O trabalho acadêmico visa construir um pensamento e por meio dele perpetuar idéias e para tanto se faz necessário buscar conceitos e análises dos teóricos e pensadores que são formadores de opinião e representam o saber científico contemporâneo. 
Sendo assim, as referências consultadas que serviram para embasar a temática do turismo de massa e dos impactos ambientais foram: Barretto (1995); Dantas (1999); Ruschmann (1997); OMT (2005, 2006); Fennell (2002); Cooper et al. (2001), onde a partir deles podese ter mais clareza sobre conceituação e histórico do turismo de massa, compreendendo a sua relação com os impactos ambientais.

Já na temática do turismo pós-moderno e da ética ambiental teve-se contato na revisão da literatura com referências importantes em cada área como: Harvey (1992); Krippendorf (2000), Van der Berghe (1994); Talaya (2004); Sampaio (2000); OMT (2001); Hall (2004); Boff (2004); Ferreira (2004). Logo, com essas citações ao longo do trabalho foi possível haver um enriquecimento nas discussões e argumentos que suscitaram a importância da pesquisa e do entendimento do conceito de gestão sustentável.

Para maior confiabilidade dos dados, preferiu-se pesquisar dados estatísticos em fontes oficiais relacionadas ao objeto de estudo e com registros recentes para o confeccionamento do artigo. Pois, de tal maneira, pode-se traçar projeções de cenários futuros de acordos com os objetivos elencados no escopo do trabalho.

Por se tratar de uma investigação de natureza qualitativa, fundamentada em uma visão humanística, que se preocupa com uma série de significados que permeiam a vida social (MINAYO, 1992). Achou-se necessário uma pesquisa documental balizada, adotando a metodologia interpretativa de Bardin, que visa conceituar e confrontar as palavras-chaves desta pesquisa, deste modo, procurou-se buscar autores de reconhecimento comprovado na literatura nacional e internacional para embasar com respaldo o trabalho em tela.

\section{CONSIDERAÇÕES FINAIS}

Este artigo orientou-se pelos debates teóricos e metodológicos sobre o fenômeno do turismo, em específico pelas abordagens do turismo de massa com seus impactos e do turismo pós-moderno com sua nova ideologia. Dentro desta lógica, procurou-se atender aos objetivos levantados neste trabalho; analisando o propósito do pós-turismo; compreendendo de que forma esta atividade pode ser sustentável; e identificando quais os desafios e perspectivas para o fomento de uma gestão mais racional.

O objetivo geral da pesquisa foi alcançado ao compreender como o modelo do turismo pós-moderno ou pós-turismo pode ser viabilizado para a implantação de uma gestão sustentável do setor, uma vez que para se tornar praticável é necessário o engajamento da comunidade, do setor privado e da esfera pública no seu planejamento. A fim de buscar alternativas e oportunidades para que haja maior segmentação do mercado turístico, fomentando assim: produtos alternativos, atrativos exóticos, serviços personalizados, tecnologias limpas, consumidores conscientes e profissionais multidisciplinados.

Entretanto, observa-se que ainda é incipiente a cooperação entre todos os setores que compõe a atividade turística, dificultando sobremaneira que essa proposta e nova concepção sejam definitivamente inseridas como forma de atrair visitantes para um novo mercado turístico.

Compreende-se pela teoria revisada que o pós-turismo nada mais é o que está sendo praticado em alguns segmentos, como o agroturismo, ecoturismo e outros que tenham características sustentáveis e substancias que são: a singularidade, a inter-relação social, a valorização da cultura local, a racionalidade dos recursos naturais, a criatividade e a busca pelo exótico. Já, nos referindo ao enfoque ambiental, este trabalho pode elucidar que tal modelo tende a minimizar os impactos negativos do turismo no meio ambiente 
contribuindo para que haja uma gestão eficiente e otimizada dos serviços ambientais e turísticos nas localidades.

Assim, infere-se que o aumento esperado do volume de turistas, com uma distribuição cada vez mais dispersa ao redor do mundo, a mudança do perfil de visitantes no turismo, com maior instrução e mais consciência do seu papel na sociedade e o desenvolvimento de novas formas associadas à natureza e à cultura é imprescindível para tornar a atividade turística mais ética. Logo, entendemos que um comportamento mais seletivo e exigente, por parte dos turistas pós-modernos, exigirá medidas consistentes no planejamento do turismo com vistas a garantir o desenvolvimento sustentável da atividade.

O artigo ora apresentado vem, assim, contribuir para a análise de sistemas de turismo. Recomenda-se sua utilização para estudos de caso em destino de turismo de massa, tanto nas áreas da administração pública voltadas para o desenvolvimento do turismo como nas dedicadas às atividades urbanas contemporâneas com potenciais turísticos. Além disso, o trabalho deverá ser útil na prática profissional dos planejadores e gestores do turismo, auxiliando-os na adoção de estratégias apropriadas para casos de destinos que visem ser sustentáveis.

\section{REFERÊNCIAS BIBLIOGRÁFICAS}

1. ANDRADE, J. Turismo: fundamentos e dimensões. São Paulo: Ática, 1992.

2. BARDIN, Laurence. Análise de conteúdo. 3. ed. Lisboa: Edições 70, 2004. 223 p.

3. BARRETTO, Margarita. Manual de iniciação ao estudo do turismo. CampinasSP: Papirus, 1995. $163 \mathrm{p}$

4. BENI. Mário Carlos. Qualidade do produto e dos serviços. In: Turismo em Análise. São Paulo. ECA/USP, 2, nov.1991, p.7-13.

5. BOFF. Leonardo. Ecologia: grito da guerra, gritos dos pobres. Rio de Janeiro: Sextante, 2004.

6. BRASIL. Ministério do Turismo. Estatísticas básicas do turismo, 2005. Disponível em < http://www.turismo.gov.br>.Acesso em 05 de maio de 2009.

7. CASTROGIOVANNI, Antonio Carlos. In: Turismo X espaço: reflexões necessárias na pós-modernidade.In: CASTROGIOVANNI, A . C.; GASTAL, S. Turismo na pósmodernidade: (dês)inquietações. Porto Alegre: EDIPUCRS, 2003, p. 43-50.

8. COOPER, Chris; FLETCHER, John; WANHILL, Stephen; GILBERT, David; SHEPHERD, Rebecca. Turismo: princípios e prática. 2. ed. Porto Alegre: Bookman, 2001.

9. DANTAS, Ana Lúcia de Faria Lucena. Atividade turística e os caminhos sustentáveis um estudo de caso no município de Rancho Queimado - SC. 1999. 95p. Dissertação (Mestrado em Engenharia de Produção. Programa de Pós-Graduação em Engenharia de Produção) - Universidade Federal de Santa Catarina, Florianópolis, 1999. Disponível em <http://teses.eps.ufsc.br/tese.asp>. Acesso em 29 de abril de 2009.

10. DIAS, Reinaldo. Turismo sustentável e meio ambiente. São Paulo: Atlas, 2003. 
11. ELLIOTT, James. Tourism: politics and public sector management. London: Routledge, 1997.

12. FENNELL, D. A. Ecoturismo: uma introdução. São Paulo: Contexto, 2002.

13. FERREIRA, Luiz Fernando. Capacitação para o ecoturismo e envolvimento das comunidades anfitriãs. In: LAGE. Beatriz Helena Gelas (orgs). Turismo, hotelaria e lazer, 3. São Paulo: Atlas, 2004.

14. HALL, Michael. Planejamento turístico: políticas, processos e relacionamentos. São Paulo: Editora Contexto, 2004.

15. HARVEY, David. Condição pós-moderna: uma pesquisa sobre as origens da mudança social. São Paulo: Loyola, 1992.

16. IGNARRA, Luiz Renato. Fundamentos do turismo. São Paulo: Pioneira Thomson Learning, 2001.

17. KRIPPENDORF, J. Sociologia do turismo: para uma nova compreensão do lazer e das viagens. São Paulo: Aleph, 2000.

18. LAGE, B. H. G.; MILONE, P. C. Impactos socioeconômicos globais do turismo. In: LAGE, B. H. G.; MILONE, P. C. (org). Turismo: teoria e prática. São Paulo: Atlas, 2000. cap.11, p.117-131.

19. MINAYO, M.C.S. O desafio do conhecimento: pesquisa qualitativa em saúde. São Paulo-Rio de Janeiro: Hucitec-Abrasco, 1992.

20. NASCIMENTO, Hermógenes Henrique Oliveira. Identidade, memória e conservação: uma análise sobre o turismo e o patrimônio cultural de Touros/RN. 2007. 81p. Monografia (Bacharelado em Turismo) - Universidade Federal do Rio Grande do Norte, Natal, 2007.

21. OMT - Organización Mundial del Tuismo. Barómetro OMT del turismo mundial, Vol. 4, 2006. Disponível em: $\leq$ http://www.world-tourism.org/facts/wtb.html>. Acesso em 02 de maio de 2009.

22. OMT - Organização Mundial do Turismo. Introdução ao turismo. São Paulo, ed. Roca, 2001.

23. OMT - Organização Mundial do Turismo. Tourism 2020 vision, 2001. Disponível em: < http://www.world-tourism.org/facts/wtb.html>. Acesso em 19 de Julho de 2009.

24. OMT - Organização Mundial do Turismo. Tourism highlights, 2005 edition. WTO: Madrid, 2005. Disponível em: <http://www.world-tourism.org/facts/wtb.html $>$. Acesso em 07 de Maio de 2009.

25. RIBEIRO, Gustavo Lins. Latin America and the development debate. Indian Journal of Social Science Vol. III, no. 2: 271-295. 1990. Disponível em: $<$ http://www.esocialsciences.com/home/index.asp>. Acesso em 10 de maio de 2009.

26. RUSCHMANN, Doris. Turismo e planejamento sustentável. Campinas: Papirus, 1997.

27. SAMPAIO, Carlos Alberto Cioce. Gestão organizacional estratégica para o desenvolvimento sustentável: uma metodologia alternativa para o planejamento turístico sustentável. Turismo: Visão e Ação. Itajaí, Vol. 3, nº 6, p.97-115, abr/set, 2000. 
28. TALAYA, Esteban Agueda. La naturaleza en el comportamiento del consumidor turístico. In: IX Congresso AECIT - El uso turístico de los espacios naturales, S.l.: s.n, 2004. Disponível em: <http://www.aecit.org/publicaciones/publicaciones.htm $>$. Acesso em 15 de Julho de 2009.

29. URRY, John. O olhar do turista - lazer e viagens nas sociedades contemporâneas. $2^{a}$. ed. São Paulo: SESC/Studio Nobel, 1996.

30. VAN DER BERGHE, Pierre. The quest for the order: ethnic tourism in San Cristóbal, México. Seattle/Londres: University of Washington Press, 1994. Disponível em: $<$ http://lap.sagepub.com/cgi/content/abstract/35/3/87> . Acesso em 10 de maio de 2009.

31. WAINBERG, J. Anotações para uma teoria do turismo: a indústria da diferença. In: GASTAL, S. (org) Turismo: nove propostas para um saber-fazer. Porto Alegre, Ed. dos Autores, 1998, p. 42-64. 